\title{
Lively commodities and encounter value
}

\author{
Maan Barua \\ School of Geography and the Environment, University of Oxford \\ South Parks Road, Oxford OX2 3QY, England; e-mail: maan.barua@ouce.ox.ac.uk
}

\begin{abstract}
Rendering nonhuman life for sale is a fundamental facet of contemporary capitalism. Political economy extensively examines how nature is commodified, but fails to analyze the difference liveliness of animals makes to processes of commodification. Drawing upon empirical work on lions and elephants in the political economies of tourism and biodiversity conservation in India, this paper proposes analytics for understanding commodification and accumulation in relational and less humanist terms. First, it develops Haraway's concepts of 'lively commodities' and 'encounter value', foregrounding animal ecologies to rework political economic categories of the commodity, labour and production in more-than-human terms. Second, it examines how lively commodities and encounter value configure political economies, mapping their specificities and economic potential. The paper advances potential diagnostics and vocabularies through which ecology and non-dualist accounts of agency might be integrated into the nature-as-resources approach of political economy.
\end{abstract}

Keywords: value, more-than-human geography, political economy, commodity, labour, production

'Of all the great motive forces handed down from the period of manufacture, horsepower is the worst, partly because a horse has a head of his own'

- $\operatorname{Marx}(1976 ;$ p.497)

\section{Introduction}

In his famous opening gambit in Capital, Marx stated that the wealth of societies in which capitalism prevailed 'appears as an immense collection of commodities' (Marx, 1976; p.125). Commodities are undeniably all-pervasive in contemporary economies, not just as inert objects, but as living, breathing things. Lions in India draw hundreds of thousands of tourists eager to collect digital trophies of these spectacular felids. Economies of zoos are largely dependent on charismatic animals: pandas gifted to Edinburgh zoo in 2011 rescued the institution from the verge of bankruptcy. Websites of international conservation NGOs are replete with images of endangered megafauna such as the Asian elephant, the rationale for which is explained by the director of one such organization: 'Elephants have the capacity to earn resources'. Indeed, animals are packaged and circulated to earn resources in present-day economies, a process rendering species into specie - metal coinage and material wealth. 
Marx's critical insight was that beneath this surface appearance of market equivalences were specific processes and relations of labour, relations extracting surplus from labour without mercy. His oeuvre has spurred a vast body of scholarship within geography and the wider social sciences examining how animals are transformed into commodities for exchange (Brockington and Duffy, 2010; Castree, 2003; Shukin, 2009). Dealing with human-animal relations primarily from social and economic standpoints, political economic analysis ${ }^{1}$ emphasizes how capital decontextualizes animals from ecosystems to produce spectacular natures (Brockington et al., 2008), enrolls charismatics to generate surplus through consumptive experiences (Duffy, 2013, 2014), besides transforming their very identity into providers of services for the economy (Neves, 2010).

Whilst a generation of political economists have argued that under late capitalism, commodities 'are emptied out both of meaning and ... material content', therefore 'deficient in affect' (Lash and Urry, 1994; p.15), geographers have consistently cautioned against such positions, suggesting they 'risk losing sight of the materiality of nature', the manner in which it influences or constrains capitalist production (Castree, 1995; p.20). Instead, they pursue 'commodity stories', shifting from the 'dead world' of artifacts to the 'living world' of sensuous, concrete and polyvalent commodities, and their role in constituting socio-political relations, or for that matter, the very processes of production (Bakker and Bridge, 2006; p.12). However, whilst questions about nonhuman and material agency are raised (Robbins, 2011), particularly how animals might resist incorporation into political economic forms, they fail to theorize nonhuman actors as constitutive elements of economic life (Bakker, 2010; Braun, 2008).

Conceptual innovations of more-than-human geography, on the other hand, frame animals as co-constitutive actors in the production of social life (Hinchliffe et al., 2005; Whatmore, 2002). They attend to affective dimensions of animal life, emphasizing how biodiversity conservation practices organize around their nonhuman charisma (Lorimer, 2007). Others foreground the lifeworlds of 'sentient commodities' (Wilkie, 2005), examining how these undergo shifts under processes of commodification (Collard, 2013). Whilst such framings of animals as actors are notably absent from a large corpus of the political economies of nature literature, more-thanhuman geography pays relatively scant attention to modes of organization centered on accumulation. As Braun perceptively remarks, much of these posthumanist approaches gravitate toward simply demonstrating the vitality and recalcitrance of nonhuman life: it is 'equally important to attend to how organization occurs' (Braun, 2008; p.675). More-than-human geography's achievements in '[adopting] a non-anthropocentric view of the agency of nature, and [interrogating] the status of nonhumans as political subjects' (Bakker, 2010; p.718), needs to be extended to their equally important status as labouring subjects within processes of valorization.

In this paper, I draw these two bodies of scholarship into conversation to examine how animals are participants in processes of production and accumulation, thereby co-constituting political economies from the outset. I focus on practices

\footnotetext{
${ }^{1}$ Certain scholars view this brand of political economy to be simultaneously and necessarily political ecology as distribution and struggles over wealth spill over into ecological domains (Castree, 2010). Others argue they have an overt focus on social relations, circumscribing ecology (Walker, 2005). One might designate approaches dealing with nature-society relations from the standpoint of their socio-economic form as 'political economy/ecology'. For brevity, I deploy the term 'political economy'.
} 
commodifying animals and rendering life for sale. Such investigations are difficult to handle solely through conceptual frameworks typically employed within conventional political economy (Bakker, 2010), and demand reworking the ontological assumptions of some of its staple categories. To this end, I build upon Haraway's (2008) terms 'lively commodities' and 'encounter value', derived from her heterodox readings of Marx, to develop a conceptual vocabulary for theorizing value, labour and production in less humanist, relational terms.

Second, I identify commodity forms of encounter value and dissect features of encounters that make them amenable for commodification and accumulation. Although Haraway (2008), and geographies of animal commodification drawing upon her work (Collard, 2013; Collard and Dempsey, 2013), emphasize the liveliness of animal commodities, attempts to elucidate how encounter value operates, or to map its specificities and characteristics, are scant. To avoid pitfalls of homogenizing high degrees of internal differentiation within what gets termed 'nature' (Bakker and Bridge, 2006), I develop an appreciation of the diverse animal ethologies and bodies currently lumped under the appellative 'lively commodity' and subsumed by the term 'encounter'. These articulations are grounded through specific animal territories involving empirical investigations of lions and Asian elephants as commodities in political economies of ecotourism and biodiversity conservation in India. I acknowledge that the paper has a focus on whole-bodied organisms, which generates specific interpretations of encounter value,. These could indeed be different if one were examining food production systems where ethologies might matter less, or if one engaged with other spaces such as dog shows or labs, sites Haraway takes us through. In conclusion, I highlight the economic potential of encounter value and discuss wider implications of this argument for scholarship on political economies of nature.

\section{Encounter value, nonhuman labour and lively commodities: an outline}

The commodity form was central to Marx's analysis of accumulation and extraction: he considered it to be the common denominator of the capitalist mode of production and saw how turning all the world into commodities was an inseparable part of its accumulative logic. Readers will be familiar with Marx's dissection of the commodity form into a doublet of use- and exchange-value. The former is 'the usefulness of a thing', the material content of wealth 'conditioned by the physical properties of the commodity' (Marx, 1976; p.126). On the other hand, commodities are only bearers of exchange-value, a 'quantitative relation ... in which use-values of one kind exchange for use-values of another kind' (Marx, 1976; p.126). Marx argued that what made the exchange of commodities commensurable in economies that incessantly generate new opportunities for production, was not 'an atom of use-value' but the living human labour embodied in them (Marx, 1976; p.128). Value, as 'socially-necessary labourtime', was the regulator of exchange relations represented in the commodity economy through money. ${ }^{2}$

Whilst Marx understood better than most that value was a process emerging through mutual relationships, his analysis resorts to a human exceptionalism. Commodities themselves are not 'eventful' for Marx (Braun and Whatmore, 2010),

\footnotetext{
${ }^{2}$ It is important to note that Marx recognized there were other forms of value out there, but his analysis, especially in Capital, is concerned with the form value takes in a capitalist mode of production (Marx, 1976; p.174, footnote 34 ).
} 
living labour which produces commodities has a humanist teleology (Shotwell, 2011), and social relations are confined to those between people (Rosdolsky, 1977). ${ }^{3}$ However, as Haraway points out, the 'commodities of interest to those who live within the regime of Lively Capital cannot be understood within the categories of the natural and the social that Marx came so close to reworking but was finally unable to do so under the goad of human exceptionalism' (Haraway, 2008; p.46). It demands a reorientation of the traditional political economic categories, for 'human labor power turns out to be only part of the story' on value, production and accumulation 'of lively capital' (Haraway, 2008; p.46).

Haraway's starting point for understanding human-animal entanglements within regimes of lively capital can be viewed as a heterodox reading of Marx's labour theory of value. This move she argues, 'raises issues not usually associated with the term biocapital', evidenced for instance in Shukin's theorizations of 'animal capital', but 'nonetheless, crucial to it' (Haraway, 2008; p.46). Shukin, extending Marx's vivid observation that fetishistic commodities appear to have a life of their own, seeks to 'animalize' commodities and render 'traces' animals leave upon 'carnal modes of production' (Shukin, 2009; p.27). Haraway's emphasis, however, is to unpack lively relations masked by objectifications of market valuation, to unveil fetishistic renditions positing species as 'specie': metal coinage and substance of exchange. As Marx does with labour, Haraway foregrounds animal lifeworlds to summon what might be if 'value becomes flesh again' (Haraway, 2008; p.45). Haraway's take on lively and actual encounters allows for 'developing histories of animal agency' missing, as Shukin admits, from her analysis of the generation of animal capital (Shukin, 2009; p.130).

'If a Marx-equivalent were writing Biocapital, volume I, today,' Haraway contends, the 'analyst would have to examine a tripartite structure: use value, exchange value and encounter value' where encounters are constituted by 'subjects of different biological species' (Haraway, 2008; p.46). Whilst explicit definitions of encounter value are elusive, Haraway's method and leads help configure an outline. First, in contrast to the notion of use value which is 'only realized ... in use or consumption' by a human subject (Marx, 1976; p.126), encounter value is posited as a 'trans-species relation' (Haraway, 2008; p.46). Second, it derives from the 'social meanings of all the "partners" to produce definite value in lively capital' (Haraway, 2008; p.62-63), be it as an 'undead but always generative commodity', as 'familial co-consumers ... or coworkers' (Haraway, 2008; p.45, p.52). Third, encounters, as world-making entanglements, have the 'power ... to produce' those very beings in the historically specific context of lively capital (Haraway, 2008; p.63). In other words, encounter value can be thought of as that process of value generation where bodies, ethologies and liveliness of an animal makes a difference to, and is constitutive of, those very relations that render or mobilize it as a commodity (Barua, 2015).

Taking encounter value seriously as an 'under-analyzed axis' of capital and its 'biotechnologies of circulation' (Haraway, 2008; p.65), evokes the question of who, and what kinds of activity, produces value. Whilst certain strands of Marx's writings

\footnotetext{
3 There are instances when Marx comes close to breaking away from this human exceptionalism in his digressions on the affordances of metals in the Grundrisse, replete with references to mineralogical states, melting points and malleability that lend to their 'friendliness' and spark 'curiosity'. The demand placed upon any metal to become the 'subject' of money, Marx notes, is 'contained in the conditions' of the materials themselves (Marx, 1973; p.173-174).
} 
acknowledge both labour and nature to be sources of value, ${ }^{4}$ in Capital, concerned with commodity production, what counts is only those forms of labour that create 'usevalues for others', whose products can be exchanged in the market (Marx, 1976; p.131). Applied off the shelf, animal labour is then embodied in certain commodities and surplus value extracted as animals give 'more than what they get in a market-driven economic system' (Haraway, 2008; p.55). However, Haraway cautions against such an approach. Animals are not wage labourers exchanging alienable labour for money in the marketplace. Animals 'produce and reproduce' but 'in neither processes are they their own "self-directed" creatures in relation to lively capital, even though enlisting their active cooperation (self-direction) is essential to their productive and reproductive jobs'. It would thus be a 'serious mistake to theorize their labour within [these] frameworks. They are paws, not hands' (Haraway, 2008; p.55).

Differentiating between the 'labour' of paws and those of hands, and 'products' generated by the two, petitions reworking of yet another staple political economic category : production. The anthropologist Tim Ingold reasons that when the human condition is viewed to transcend nature, thereby externalizing the latter and making it stand as raw material for projects of construction, production inevitably gets conflated with making (Ingold, 2000). This conflation, permeating much of nature-as-resource political economy, rests on the notion that human reason - the deliberate planning of activity by intentional and self-conscious agents - provides a form at the outset and shapes up material from a raw to final state. ${ }^{5}$ Value is thus bestowed upon what is 'given' in nature. It makes no difference whether productive activity is 'represented by the labour of the artisan, the manufacture of equipment, or that of the farmer or stockbreeder in the husbandry of plants and animals' for all are 'conceived as instances of productive making' (Ingold, 2000; p.80). In this view, labours of animals cannot be deemed productive activity precisely because they lack prior intent and do not make things. ${ }^{6}$

But how can one 'make' a lively commodity, be it a lion, an elephant, or for that matter, Haraway's canines? Ingold persuasively argues that the work of farmers or herdsmen does not make crops or livestock, 'but rather serves to set up certain conditions of development within which plants and animals take on their particular forms and behavioural dispositions' (Ingold, 2000; p.77). Productive activity is about processes of growth, where human beings do not so much make the material world as play their part along with other lively creatures in the world's transformation of itself. The same holds for artefacts: their forms are not given in advance but generated in and through practical movements of one or more skilled agents in their sensuous

\footnotetext{
${ }^{4}$ In the Critique of the Gotha Programme, Marx spells out: 'Labour is not the source of all wealth. Nature is just as much the source of use values ... as labour. Labour is itself is only the manifestation of a force of nature, human labour power' (Marx, 1974; p.342). This view gradually recedes from later economic writings such as Capital (also see Footnote 2 above).

5 Marx's view on whether ideas or the consumption of products influences production can appear contradictory, unless understood in terms of his dialectical mode of argument; best exemplified in the 1857 introduction to the Grundrisse (Marx, 1973). Expounding upon this is beyond the scope of this paper, but for a nuanced reading see Ingold (2011; p.4-6).

6 This is a position Marx propounded in Capital, particularly when contrasting human and nonhuman productive activity in the chapter on the labour process (Marx, 1976; p.284).
} 
engagement with materials (Ingold, 2000). Animals are not mere raw material inhabiting nature external to the social world of persons. Rather, "both humans and the animals and plants on which they depend for a livelihood must be regarded as fellow participants in the same world' (Ingold, 2000; p.87).

This reorientation of 'relations of production' provides firm ground for theorizing encounter value. Once understood intransitively, and dissociated from making, productive activity can be viewed as processes of growth, of working with materials, where nonhuman animals play an integral role. The absolute dichotomy between the labours of paws and those of hands becomes a moot point, for both submit to a productive dynamic immanent to the world. Following Ingold, I term such productive activity embedded in more-than-human relations tasks as opposed to work or labour (Ingold, 2000). ${ }^{7}$ Humans and animals are situated at the center of their productive activity when conducting tasks, temporalities of which are rhythmic, intrinsic to and emerging from movement itself, not sidereal or chronological as in capital's division of the working day (Ingold, 2000). They are at their tasks rather than confronting them, the latter exemplified by alienated labour lucidly dissected by Marx (Marx, 1977), and put to exchange as a commodity measurable by units of time in return for wages (Marx, 1976). Tasks, performed through a range of carnal and ethological registers, are enacted in the presence of others whose own performances necessarily have bearings on the skilled agent's activity, human or animal. These skills and knowledges, cutting across porous bodies and human-animal divides, is one way to ground and articulate Haraway's allusions to labours 'of mutually adapted partners', 'located in zones between work and sport' (Haraway, 2008; p.56, p.62). To further flesh out how they 'produce definite value in lively capital' (Haraway, 2008; p.63), I will now turn to two instances where animals are mobilized for the process of accumulation.

\section{Encounter value and lively commodities in action}

The previous section sketches a conceptual vocabulary to understand value in relational, more-than-human terms. To further flesh out specifics of value-generation processes, how they are configured by particular animal bodies and ethologies in situated spatial contexts beyond the outline provided by Haraway, I now turn to political economies of ecotourism and biodiversity conservation in India mobilizing lions and elephants as lively commodities. ${ }^{8}$ By unpacking differential labours performed by nonhuman animals and mapping multitudinous processes of commodification, I advance understandings of how encounter value is harnessed and operationalized.

\footnotetext{
${ }^{7}$ In German, the word arbeit can refer to 'labour' and 'work'. Engels singles out 'work' as the term that most clearly expresses Marx's intended meaning of conscious, purposive activity in the productive process. The labour which creates use-value, and counts qualitatively is work, whilst that which creates value and counts quantitatively is labour (see: Ollman, 1976).

${ }^{8}$ The material presented here draws upon field- and archival work carried out in India. The two species were selected for their well-established presence in public, policy and economic spheres. Research on lions, conducted in 2014, involved examining historical, legal and policy documents, besides a systematic analysis of newspaper articles published in India in the last ten years. This was triangulated with interviews with experts in conservation and tourism sectors. Work on elephants (2007-2011), focused on the two most important NGOs in India for whom elephant conservation was an integral part of their mission. Both had strong influence on conservation policy. Research involved key informant interviews, besides accessing documents and promotional material.
} 


\section{Lions and the lively political economies of ecotourism}

The Asiatic lion is a forceful example of encounter value at work in the political economies of ecotourism. Almost entirely extirpated by the end of the $19^{\text {th }}$ century, populations of the creature survive only in the Gir National Park and its environs in Gujarat, western India. Gujarat actively markets lions to attract visitors to the state: high-profile Bollywood celebrities are appointed brand ambassadors to endorse 'the pride of Gujarat', its state tourism logo even changed to a lion in 2010. At work is here a very successful process of commodification: in recent years Gir has registered a 139\% growth in international visitors and witnessed substantial tourism revenue hikes (Smitha, 2012).

The commodity life of Gir lions, far from being trans-historical, emerged through specific historical-material geographies. Efforts to conserve lions page back to the latter part of the $19^{\text {th }}$ century when the sixth Nawab of Junagadh took strong measures to conserve the last remaining beasts in his princely state. A prized trophy animal in colonial India, lions were 'reputed to afford better sport than the tiger' on grounds that their 'attack [was] more open and certain; a peculiarity arising either from the noble nature of the jungle king, or from the country which he haunts being less favourable for a retreat than the thick morasses frequented by the tiger' (Mundy, 1832; p.330, emphasis added). Shooting fierce predators on foot was integral to embodied assertions of colonial authority, enabling Britons to establish manliness and superiority over Indian 'natives'. The desirability of lions in the eyes of colonial and princely hunters, however, was not simply one of inscribing meanings upon felids. Topographies of the encounter, ethologies of the creature, or in Mundy's words, what lions afforded sportsmen, were vital.

The term afford is critical here, for it offers a relational diagnostic to appraise trans-species encounters. Coined by James Gibson, 'affordance' may be understood as what environments, organisms or things furnish for the purposes of a subject (Gibson, 1986). Neither arbitrary nor infinitely malleable, affordances are realized through discovering meaning in the very processes of interaction and use (Ingold, 2011). The lion's 'noble' nature was thus constituted through encounters, emerging from dynamic interactions between perceiver and perceived, in part configured by its behavioural affordances.

The Nawab's ban on lion hunting came at a time when it was virtually extirpated by British sportsmen and Indian princely elites. This enforcement, however, also established Junagadh's monopoly over access to shoot these sought-after felids. Constant claims were made on lions by eager hunters, with instances when neighbouring princes even luring lions into their territory, but the Nawab and his successors seldom granted permission (Divyabhanusinh, 2006). Exceptions were made when political purchase could be harnessed through gift-exchange in the form of lions. Dignitaries such as Viceroys and Governors of Bombay were 'offered' animals during their visits to Junagadh, occasions that mobilized state resources to the fullest extent possible to ensure a successful shoot.

Channeling tasks carried out by lions were vital for such bloody encounters to take place. Lions were habituated months in advance through live baits. Specific animals, generally those with prominent manes, were regularly fed buffalo calves to localize movements and 'anchor' the quarry (Divyabhanusinh, 2005), for shoots were a matter of prestige. A visiting dignitary's failure to bag a lion was a source of 
embarrassment for the hosts (Fenton, 1911). There were instances when the Nawab gave permission to shoot additional animals if visiting dignitaries only managed to bag a lioness (Kincaid, 2008 [1935]). Bodily configurations of individual lions, their phenotypic affordances, thus played an equally vital role in such transactions. Wellformed manes, generally borne by males, accentuated the 'face' of the creature, enhancing bold and regal qualities sportsmen associated with the felids. The sex, 'faces' and manes of lions were pivotal in co-configuring the masculine cult of hunting, reflected in photographs recording shoots where dignitaries posed with the quarry laid out to highlight these features.

The emergence of lions as lively commodities began with the rise of tourism in independent India, which witnessed the abolishment of the Junagadh princely state. Baiting was no longer practiced for the hunt, but to attract tourists, commodifying encounters, increasing their duration and velocity with lasting effects on the creatures' ethologies. A successful 'lion show' was held for Prime Minister Jawaharlal Nehru during his visit to Gir in 1956 (Rangarajan, 2013). The Gujarat Forest Department, driven by revenue-generating motives, soon institutionalized consumptive encounters by 'anchoring' lions to specific locations. Contrary to the colonial hunt, live buffalo baits were offered to lions once tourists left. Sightings became more certain and thousands of visitors flocked to Gir. Tourist numbers doubled in a span of five years during the 1960s (Joslin, 1970), accompanied by a rise in tourism revenues.

Lions' umwelts (von Uexküll, 1957), their specific, meaningful ethologies of locating, killing and feeding upon prey constituted political economies of ecotourism from the outset. Although habituation and anchoring were necessary for commodification, they were not inscriptive activities but a process of working with lions' space-time rhythms, of synchronizing their tasks with movements of eager spectators desiring to view their charismatic bodies and ethologies. Furthermore, the trans-actions constituting this lively political economy were sustained partly because the activity of being drawn to bait was value-forming for the lions themselves. Here, value is not about use or exchange along a humanist axis of calibration, but what von Uexküll terms 'ton', or quality, where a thing has significance for an animal by virtue of it being drawn into relations fostered by the creature's own activities (von Uexküll, 1982).

Biologists studying Gir lions commented on the animals becoming 'accustomed to participating in "lion shows" (Joslin, 1970; p.29). Hunting behaviours of lions underwent shifts, with animals becoming 'daytime [hunters] instead of the nocturnal predator of wildlife of earlier times' (Berwick, 1976; p.31). By the late 1960s, baits attracted approximately twenty percent of the lion population. Moves to maximize encounter value through baiting, although discontinued in 1987, had a modifying effect as they transformed ethologies of Gir lions. Lion densities in areas with baits increased, the animals becoming 'as close to trusting people as wild predators can' (Rangarajan, 2013; p.126). Archival photographs of Nehru's 1956 visit show him dressed in a drab overcoat provided by the forest department, for lions then were not used to crowds or colourful clothing (Divyabhanusinh, 2005; photograph of p.172). With the rise of 'lion shows', the animals became more accustomed, even allowing tourists to approach on foot.

Heterogeneous forms of labour and multiple temporalities constituted this lively political economy. Erstwhile trackers of the Junagadh state were employed at low wages to help detect lions and enable much-sought encounters. Equally vital were lions' tasks 
of locating, stalking and killing prey, bodily and reproductive labours without which no economic collective would have been composed. If a sidereal, chronological time divided the working day of trackers, the same did not hold for temporalities of lions' taskscapes. Rather people worked with space-time rhythms of felids to ensure, and generate surplus from the encounter. Instances when 'anchored' lions refused to show up were not infrequent, much to the disappointment of visitors and dignitaries, but also serving as a reminder of the recalcitrance of taskscapes, which, unlike wage labour, cannot entirely be subsumed by capital.

Specific conditions of growth were set up for the lively lion commodity in Gir, constituting a 'contact zone' where trajectories of lions, pastoralists, the state and owners of capital knotted into one another as 'world-making entanglements' (Haraway, 2008; p.4). However, accumulation through encounters did not proceed without their share of coercion and dispossession. Efforts to sustain spectacular encounters, within a people-free 'wilderness', led to forcible displacement of over eight hundred pastoralist Maldhari families in 1972. Rehabilitation of the displaced was poor, stripping cattle graziers from their means of subsistence and hurling many into wage labour (Randeria, 2003). Furthermore, sustenance of conditions of growth distributed costs unequally: livestock continues to predominate lions' diets, affecting Maldharis as cattle comprise their primary source of livelihood and income (Banerjee et al., 2013).

The constitutive role of encounter value in the political economies of ecotourism is further evidenced in recent debates over lion translocation. Conservationists in the 1990s, concerned over extinction risks faced by a single population, proposed translocating a few animals to the Kuno sanctuary in adjacent Madhya Pradesh. Gujarat vehemently opposed parting with their 'pride', arguing that the state 'is their home and we are conserving it' (Anon., 2007a). Couched behind such rhetoric of uniqueness was the fear of a 'tourism threat', as translocations would 'divert influx of a considerable number of lion-watcher tourists to Madhya Pradesh' (Anon., 2007b). A senior forest department official from Gujarat even refuted the plan's conservation rationale, stating it was 'a coup of sorts' for Madhya Pradesh would then promote encounters with 'panthers, tigers and lions all at one place' (Smitha, 2013), a menagerie of charismatics unparalleled elsewhere in India. At the Kuno end, the promise of receiving spectacular felids had significant political economic consequences. Real estate prices went up threefolds as corporate interest in tourism was invigorated by the potential future lion encounters would generate (Naveen, 2013). Gujarat's refusal to give up their lively commodities has led to a long legal battle between the two states. A tug of war over lion translocation continues, but debates aside, the strong currency encounter value has in motivating ownership over lions, and the generative role their liveliness plays in configuring the scope of ecotourism, are difficult to dispute.

\section{Elephants and the conservationist mode of production}

To further map differential facets of encounter value and specifics of its operation in other contact zones, I now turn to yet another lively commodity: the Asian elephant. A religious icon, lovable animal and endangered species, elephants are what conservationists call 'flagship species': animals serving as symbols and rallying points for various conservation goals, particularly raising NGO profiles, increasing membership and raising funds (Caro, 2010). In India, two prominent and influential 
conservation NGOs - the World Wide Fund for Nature (WWF) and the Wildlife Trust of India (WTI) - effectively deploy elephants to catalyze such actions. Prodigious vehicles for generating funds, elephants provide an excellent opportunity for understanding encounter value's integral role in configuring 'conservationist modes of production', a term deployed by geographers to refer to capital's appropriation of wildlife by forging conditions for its transformation into commodities (Brockington and Scholfield, 2010).

The effectiveness of elephants as rallying points does not stem from inscriptive logics of symbolism alone. It is in part enabled by the animal's megafaunal ecologies. The world's largest living land mammals, elephants have large spatial requirements. Their home ranges, constituted by long-distance movement, collective memory, and sentient knowledge of food sources, span across landscapes, affording conservation organizations opportunities to 'maintain biological diversity and ecological integrity over extensive areas' (WWF, 2006). Ecological affordances, critical for framing elephants' flagship potential within epistemic rationales of conservation science, are however only part of the story: a deeper goal is to shift renditions of flagships from a scientific to an emotional register. Conservation organizations are well aware of the emotions elephants generate, and harness public sentiment to materialize conservation imperatives: "People, whether they come from an elephant-range state or not, empathize with the elephant. They want it safe as they think it is an intelligent social animal with memory, consciousness and other things" (Director, WTI).

Emotional registers of conservation are in part shaped by the empathy elephants' ethologies and bodies evoke. Big like us, elephants establish strong social bonds, have a highly developed cognitive capacity, express emotions and mourn their dead, lively features brought into public purview through contact zones of captivity and virtual renditions of their sentient lives. In captivity, tactile encounters are a vital medium through which cosmopolitan publics 'get in touch' with the elephant, and are in turn 'touched' by concerns over their welfare and plight (Barua, 2014b). Elephant orphanages, camps and safari parks across Asia increasingly sell packages for tourists to interact with the creatures, where tactile encounters of riding, bathing and caring for elephants are integral components (Duffy, 2013, 2014). Bodily configurations of elephants, including homeothermy, hair, dry skin, condition the desirability of commodified haptic experiences, which would be different and unappealing if Proboscidean bodies were scaly, slimy or rough (Lorimer, 2007).

The liveliness of elephants, their ability 'to touch' people through carnal, aesthetic and ethological encounters, from the outset constitutes and makes a difference to those situations where they are mobilized as a fundraising commodity. This is explicitly stated by the director of WWF-India's Species Programme: "If you appeal to the public, then megafauna are very important ... Imagine raising funds for the Pigmy Hog as opposed to the elephant ... Who is likely to cut eyes small?" The Pigmy Hog, although critically endangered, does not afford the same fundraising potential: "For you and me it's very important, but for the guy sitting down the road in London, it's a hog..." "Elephants," on the other hand "have the capacity to earn resources ... they have earning appeal and earn biodiversity conservation".

Yet, such processes of generating spectacular encounters and transforming them into monetary currency have deep bearings upon elephants' bodies and ethologies. In captivity, elephants' ability to 'earn' capital is contingent upon exercising domination over their tasks, of making them benign, besides speeding rates of encounters. The latter is evidenced in the rising phenomenon of 'celebrity elephants' immensely popular 
with publics in southern India, where tusked bulls are made to participate in ceremonies and processions on almost daily basis. Lucrative rental fees, exceeding US\$ 1,000 per day, motivates owners to make animals participate in over two hundred festivals annually (Romig, 2013). Elephants' reproductive and social lives are severely constrained. The encounter value spectacular bulls generate has triggered significant past off-take of tusked animals from the wild, shrinking gene pools for tusks and even inducing tusklessness in certain wild populations (Kurt et al., 1995). Contrary to the social, nomadic lives of free-ranging animals, a typical celebrity elephant is a 'celibate male chained to one spot ... isolated from other elephants except when working' (Romig, 2013; no page). Fissured social relations cause boredom and depression in captive individuals (Bradshaw, 2009); stressed, maltreated and overworked bulls are known to kill their handlers (Romig, 2013). These violent relations are selectively kept out of public purview when lively commodities are mobilized for consumptive encounters and exchange.

Critical for accumulation within conservationist modes of production are spectacular encounters with virtual images of charismatics (Brockington et al., 2008). Such encounters involve micropolitical arrangements streamlining and manipulating appealing features of elephants. "Birds and reptiles don't get you money. Even whales do not get you money. But elephants are able to. What makes the elephant so effective ... is that they have forward-facing eyes" (Director, WTI). Visual materials crafted by both organizations amplify forward-facing eyes: frontal images of elephants stare at the viewer, often with captions highlighting the creature's plight. Presenting animals with a 'face' not just adds an ethical dimension to human-animal encounters (Jones, 2000), but is crucial for bringing people into folds of consumptive experience. Not dissimilar to tropes of advertising, choreography of faces emphasizes neoteny and cuteness, giving a grip to encounters to elicit desired emotional responses. Conservation organizations constantly harness this 'face value' (Thrift, 2010), which gains currency through repeated presentation and circulation.

Furthermore, in virtual contact zones, there is a micropolitical channeling of other disembodied, semiotic currencies to intensify charismatic ethologies and desiregenerating features. Websites of WWF and WTI furnish statistics of elephants' longevity, social bonds and intelligence. They are replete with manipulated, close-up images accentuating body parts such as the trunk, eyes and skin. Elephants' lives are ever more visible than before, for ephemeral encounters in the open are stabilized, circulating with immense velocity through web pages and videos.

However, such orchestrated encounters are also fetishistic (Shukin, 2009). Spectacular elephants are far removed from the space-time rhythms of living counterparts; charismatic renditions omit undesirable encounters; and the very subjects of such imagery are unable to challenge the desiring gaze (Davies, 2000). In contrast, lively encounters between people and elephants in rural India are filled with asymmetries. Elephants' propensity for planted crops, due to their better taste and nutritive values, lead them to form novel social formations, negotiate risk-laden environments and even calibrate temporalities with farmers' activities (Barua, 2014a). Crop-raiding is value-forming for elephants, but constitute undesirable encounters for the rural poor. Besides livelihood loss, impacts of conflict include hidden opportunity and transaction costs, generally borne by weakest socio-economic sections of society (Barua, 2014c). 
Fetishistic renditions mobilizing elephants' charisma also mask political events and 'postcolonial struggles ... of a milieu inhabiting fissured ecologies' (Barua, 2014c; p.1475). For instance, escalating conflict led to a spate of elephant poisonings in the northeast Indian state of Assam in the 2000s, with irate villagers scrawling the words 'Paddy thief elephant Laden' on the body of one carcass . Such acts of vilification are not uncommon in India, with anger directed toward elephants and the state or organizations seeking to conserve them. Local protests and opposition can stall conservation initiatives and jeopardize goals flagships are used to leverage (Barua, 2014 b). In a more symmetrical vein, impacts of such conflict are also borne by elephants. Individuals respond to retributive action, sometimes expressed in the form of calculated, directed attacks on humans that have harmed them in the past (Barua, 2014c; Bradshaw, 2009).

Like websites featuring celebrity elephants, where violent attacks on handlers are masked (Romig, 2013), dire aspects of conflict are seldom profiled in fundraising campaigns of the two conservation NGOs. As a WTI representative remarked, "Donors feel very comfortable if you work with species such as the elephant". This appeal for fundraising purposes only works when the elephant is portrayed as a purportedly apolitical commodity, where encounters challenging its unanimous charisma or coercive conditions of growth constraining elephants' reproductive and social lives are concealed. Capital's appropriation of wildlife through conservationist modes of production, whilst contingent upon generating encounter value, can thus proceed at the cost of both elephants and the rural poor with whom they cohabit.

\section{Topologies of encounter value}

Both case studies discussed above persuasively illustrate how liveliness and encounter value configure the scope and organization of political economies rendering life for sale. Encounter value, as a relational achievement, is specific to world-making entanglements of heterogeneous organisms, technologies and bodies. It is a process, unfolding through multimodal, sensuous labouring activities of more-than-human company, but rendered into a thing when commodified and made to circulate in markets for purposes of valorization. In this section, I now compare and characterize commodity forms of encounter value, and further dissect features of encounters that make them amenable to commodification, before highlighting the economic significance of the concept.

\section{Encounter value and its commodity form}

In its commodity form, encounters become a currency of exchange, generating capital for those harnessing the liveliness of animals. Although not an exhaustive catalogue, the empirical investigations point to three distinct commodity forms of encounter value. The first pertains to rendering experiences of encounters in the open into consumptive products, witnessed in the case of lion ecotourism. Contrary to conventional political economic analyses of neoliberal ecotourism, where only human labouring activities count in the value generation process (see e.g. Brockington et al., 2008; Neves, 2010), sensuous, multi-temporal tasks of lions constitute that which is commodified from the outset, for no value would be produced without them. Heterogeneous forms of labour, or tasks, carried out by both able-bodied humans and animals go into the 'production' of consumptive ecotourism experiences, where production is intransitive, with no fixed design stamped upon nature to shape it up into a final form (cf. Marx, 1976). Rather, specific conditions of growth are set up for lively commodities, through the constitution 
of reserves, their ethologies modulated to enhance likelihoods of value-generating encounters.

Second, the commodity form in the context of captivity extends to traffic in animal bodies themselves, witnessed in the circulation and exchange of elephants through trade. They also include commodified haptic encounters, packaged and sold in elephant orphanages and riding camps. Exchange of both lively commodities and desirable, tactile encounters involve transactions, but not of value generated solely through human labour embodied in elephant capture and training. Rather, exchange is better understood as trans-actions, constituted with Proboscidean bodies and their

sentient ethologies. Such trans-actions are not founded on differences in spheres of human and animal productive activity, but in fact spark both into being. They have, as Haraway notes, the power to produce those very beings in historically specific contexts of lively capital (Haraway, 2008).

The third mode involves spectacular, virtual encounters, manipulated and streamlined to promote conservation imperatives. The encounter is with disembodied renditions, which amplify the charisma of animals and make them desirable for the voyeuristic gaze. Far removed from space-time rhythms of animals, the commodity form lends to what political economists have called 'spectacular accumulation' (Brockington et al., 2008), a profit-driven mobilization of fetishized images and ideas, cleaved from social and political conditions of their production. Spectacular accumulation revolves around the encounter as both a commodity and a means of selling other commodities, including tourism packages, merchandise and the like.

Whilst specific ecologies are effaced, virtual encounters are fluid and have immense velocity. They are easily generated and proliferate as semiotic currency, thereby fast becoming a conduit for the creeping neoliberalization of nature. In contrast, lively commodities in the open are a more 'viscous' form of capital (HarrissWhite, 2003). Ecological, material and political constraints restrict their flow and circulation, the politics surrounding lion translocation being a case in point. Liveliness thus influences the life of commodities, differentially affecting their exchange, circulation and flow.

\section{Harnessing encounter value: ethologies, bodies, contact zones}

The two examples of lively commodities in action help specify dimensions of encounters rendering them amenable for appropriation and exchange. An animal's umwelt, the activities it finds meaningful or value-forming (von Uexküll, 1982), plays an important role in commodification. For instance, spectacular encounters with hunting lions or companionate elephants are marketable due to the creatures' ethologies and actions, their own historically-situated bodily needs. Equally, other tasks they carry out, including livestock depredation and crop-raiding, ethologically constrain capture by market and conservationist logics as they constitute undesirable encounters for those cohabiting with lions and elephants on the ground. It is these multimodal forms of valuation, operating beyond simply humanist axes of assessment and calibration, that Haraway evokes when attaching the 'trans-species' prefix to 'encounter value' (Haraway, 2008; p.46). Recalcitrant ethologies indicate that nature does not form a rallying site where an agreeable economic collective is readily composed.

Encounter value is also configured by what I term 'technologies of detection'. They not only include an organism's 'detectability', described in work on charisma to be contingent upon its phenotypic features, medium of inhabitation, speed and degree of 
movement (Lorimer, 2007), but also sensing technologies and skilled human labour. Lively commodities are participants in such modes of composition: animals can get habituated, or as other studies indicate, modify activities to avoid being seen (Neves, 2010). Technologies of detection, far from being neutral, are instrumental in forging the very relations of capitalist accumulation. Baiting and hire of low-paid trackers in lion ecotourism are an example. The rise of the SCUBA diving industry is illustrative of how technological innovation enables new economic collectives to form.

A further set of parameters influencing how lively commodities are valued by sentient able-bodied humans pertains to affordances of animal bodies. Whilst bodies cannot be cleaved from an organism's ethologies (Deleuze, 1988), corporeal affordances nonetheless provide a set of useful diagnostics to unpack value in relational terms. For instance, the empirics highlight how forward-facing eyes are vital for staging intense and desirable encounters. Presenting animals with a 'face', through images, film or other media orchestrates encounters for spectacular accumulation. Economic currency is generated in the form of 'face value' (Thrift, 2010), produced from a richly heterogeneous spectrum of affordances by reiterating certain variants - the 'face' - over others. Face value, for encounters 'depend on the face-to-face meeting of living, meaning-generating beings across species' (Haraway, 2008; p.63). Organisms that do not readily afford face-to-face encounters are more difficult to mobilize, unless anthropomorphized. Similarly, dry, homeothermal mammalian bodies afford haptic interactions, thus influencing the commodification of tactile encounters in captivity.

Finally, there are specific geographies to the processes of value generation and its concomitant commodification. The 'contact zones' where species meet (Haraway, 2008), are variegated with different potentials for generating encounters. The case studies highlight how encounters with animals in the wild are ephemeral and subject to recalcitrance: they may or may not take place. Commercially successful game parks tend to be those where large numbers of charismatics can be seen, but the conditions of growth set up for lively commodities can proceed through fraught histories of enclosure and dispossession, Gir national park being illustrative of what is a wider phenomenon across South Asia and Africa (Brockington et al., 2008). Captivity, in contrast, provides greater durability to encounters through its confinement of animal lifeworlds. Captivity, however, is a form of primitive accumulation, where lives of animals are torn from ecological relations and hurled into labours of producing for exchange, where they 'live and die for abstract capital rather than for and with one another' (Shukin, 2009; p.214). In virtual contact zones, sharpened, choreographed encounters heighten the charisma of lively commodities. Encounters are engineered such that they have a fetishistic currency of their own, circulating with immense velocity, but at the cost of effacing the ecologies of animals with no room for the subject to respond.

\section{Encounter value and its economic potential}

Encounter value matters in political economic analysis when actual processes of production and circulation are considered. Ethologies and taskscapes of animals have direct bearings upon the 'production' of consumptive experiences, be they virtual, in the open or in captivity. Thus, animals' labours and the encounter value they generate configure and shape landscapes of capitalist accumulation, not merely introduce recalcitrance into economic processes with which they come into contact (Bakker and 
Bridge, 2006; Castree, 1995). The significance of encounter value is that it conceptualizes political economies as constituted by liveliness from the outset, rather than them being 'embedded' in some material or ecological base as certain analysts suggest. The parameters influencing the ambit of economic activity traced in this paper, are thus not existents given in advance of beings and prior to their relating, but occurents, inseparable from the dynamic interactions between perceiver and perceived that spark them into being.

Whilst Marx emphasized the predominance of exchange over use value in capitalist modes of production (Marx, 1976; Rosdolsky, 1977), pre-empting later views that commodities are 'emptied of meaning and substance' (Lash and Urry, 1994; p.12), categories of use and exchange are not alone sufficient for understanding how value is generated from a commodity that is alive. Encounter value, its emphasis on ethological and corporeal potentials of animals, enables one to account for how liveliness coconstructs the meaning, allure and desirability of commodities. 'Commodity stories' are recast to accommodate materiality and liveliness, their heterogeneity which differentially influences economic contexts of commodity production and the spatial topologies of their circulation.

Encounter value modifies social and ecological relations co-constituting productive economic activity. Commercialization of encounters, witnessed in baiting Gir lions and speeding up elephant labours in captivity, has lasting effects on animals' ethologies. Such generation of encounters for the purpose of exchange, resulting in an increase in their duration and velocity, can efface specific ecologies of lively commodities, rendering them subservient to accumulative logics of 'abstract capital' (Shukin, 2009), most evident in virtual encounters cleaved from the lives of the animals themselves. It would however be a mistake to assume that domination of exchange value annuls liveliness altogether, for exchange does not occur without specific encounters taking hold and giving grip to trans-actions across species. It is this dynamic between encounter, use and exchange that the analyst must consider, poignant in Haraway's method of examining a tripartite structure (Haraway, 2008).

Encounter value further constitutes the scope of economic activity in that surplus is generated from specific processes and nonhuman labour rendered into commodity form. Consequently, states of encounter always need to be maintained if economies of ecotourism and biodiversity conservation are to be sustained. This is yet another way to understand logics underpinning maintenance of animal populations, of rendering animals present through practices of biodiversity conservation. The historical transition of lions from hunted game to living commodities for ecotourism is exemplary. Although beyond the scope of this paper, this role of encounter value can be a productive for interrogating debates on maintaining ecological processes and the commodified 'services' they provide.

\section{Conclusions}

In this paper, I have developed the concept of encounter value as a constitutive force and axis of capital in economies rendering life for sale. I have traced some of its commodity forms and have highlighted the economic potential of encounter value. Furthermore, I have empirically mapped different ethological and corporeal parameters that render possible, or constrain, commodification of sentient life. These mappings are specific to the animal territories explored, but nonetheless provide an important entry 
point for putting the above concepts to work. To conclude, I will briefly summarize and make explicit the significance of this analysis for developing relational frameworks that go beyond humanist biases of political economy, whilst retaining correctives they offer for understanding organization at times elusive in more-than-human geography.

Firstly, encounter value, concerned with heterogeneous forms of labour, moves beyond theorizations of surplus in contemporary analyses of 'animal capital'. Such approaches seek to unravel the fetishism masking spectacular commodities to elicit how animal life 'leaves traces in the histories of production', but formulations of what constitutes productive labour are resolutely humanist. Surplus is derived by 'skimming of extra value off animal remains' (Shukin, 2009; p.114). Labouring nonhuman bodies are inert, not generative of the value coagulated in 'animal capital' other than as raw material.

Such evacuation of multi-temporal tasks performed by more-than-human company from political economic theorizations of commodification and value arises from its legacy of conflating productive activity with making (Ingold, 2000). It is evident from the political economies of ecotourism and biodiversity conservation assayed in this paper that humans work with animals and set conditions for their growth, rather than make lively commodities. Production, decoupled from making, is an intransitive activity involving trans-actions with lively creatures and materials themselves. Both Gir lions and Asian elephants provide compelling insights. 'Making' too seeps into the language of Haraway (2008; p.65), and others following her oeuvre (Collard and Dempsey, 2013). Although she does not subscribe to the same notions of animals being inert commodities, 'made' in a capitalist mode of production, her deployment of the term 'making' is still problematic, given the exorcist tendencies it thrusts into political economy, a sifting out of nonhuman animals to which Haraway's own project is fundamentally opposed.

Secondly, whilst this paper draws upon explorations of nonhuman charisma in more-than-human geography elucidating how animals' ethologies and liveliness impel particular constituencies to take interest in living organisms (Lorimer, 2007), it engages with questions of value, labour and fetishism sidestepped in their analyses of how organization occurs (Braun, 2008). The explanatory schema of nonhuman charisma as an organizing force is essentially Weberian: charismatic authority forms an organizing force based on cults and followings, an order of enchantment that is more alluring than the mundane and bureaucratic workings of the economy (Weber, 1978). In the political economies of nature, nonhuman charisma plays an organizing role because it 'acts as a vital counterforce to what some ... perceive to be the disenchanted discourse and practice of much conservation biology ... the "bureaucratic Fordism" pervading institutional planning and arrangements (Lorimer, 2007; p.926). However, its emphasis on enchantment does not explain the logics of accumulation or how value is generated through the traffic in spectacular, lively commodities.

Heterogeneous labour, relations of production and growth under capital recede from purview when micropolitical arrangements amplify and mobilize nonhuman charisma. Marx's analogy of commodity fetishism, his insight that as fetishes, commodities can be 'charismatic in its lifelike effects' (Shukin, 2009; p.19), becomes pertinent when nonhuman charisma is situated within specific geographical histories of capitalist accumulation, illustrated by both empirical examples discussed above. Contrary to the unanimous, conformist, and at times trans-historical rationality charismatics bestow upon consumptive experiences, encounter value foregrounds the 
material relations and more-than-human processes at work in rendering accumulation possible. The ethologies and bodies that shape domains of neoliberal nature are not pregiven substrates but are themselves historical outcomes of material and representational practices. ${ }^{9}$

Geographers and political economists concerned with theses about the production of nature have long recognized the need to develop a 'theoretical framework wherein historical materialist accounts are able to register and incorporate nature's materiality' (Castree, 1995; p.22). However, concerns are constantly raised that coconstitution of the economic fabric by more-than-human collectives is 'difficult to handle within the conceptual frameworks typically employed' in political economy literatures (Bakker, 2010; p.717). The analytics developed in this paper, particularly the trinity of concepts of lively commodities, encounter value and tasks or nonhuman labour, provides a valuable framework to interrogate questions about nature as a constitutive political economic force. Drawing upon, and expanding, Ingold's distinctions between dwelling and commodification (Ingold, 2000), this framework sets up what I term a 'lively perspective' (Table 1), the contours of which have been flagged up earlier in this paper. Unlike staple categories of political economy, commodities are eventful and value is relational, generated through heterogeneous tasks within temporalities composed by human-animal rhythms. Who or what constitutes relations of production is not policed in advance.

The approach proposed and developed in this paper has much to offer in terms of going beyond the humanistic biases of nature-as-resource approaches of political economy, whilst retaining its analytical purchase in understanding logics of accumulation. The liveliness of commodities has always lurked in political economic analyses: as Marx shrewdly noted, the limitations of deploying horses in manufacture is partly because they have heads of their own. The point however is not just about asserting the unruliness of animals or materials, but to account for them right from the outset, constituted historically and constitutive of economies. Echoing Haraway's call, it is indeed 'time to think harder about encounter value' (Haraway, 2008; p.62). Easier said than done, yet likely to offer great dividends for geographical engagements with political economy.

Table 1: The lively and commodity perspectives on political economy

\begin{tabular}{|c|c|c|}
\hline & Commodity perspective & Lively perspective \\
\hline Commodity & Uneventful & Eventful \\
\hline Labouring activity & $\begin{array}{l}\text { Labour (quantitative) vs. } \\
\text { work (qualitative) }\end{array}$ & Tasks \\
\hline
\end{tabular}

\footnotetext{
${ }^{9}$ The cartographies of accumulation tracked herein are developed through postcolonial contexts. These do not necessarily rest on pasts posited by capital as a precondition (Chakrabarty, 2007), and therefore need to be understood in their specificity. Articulations of more-than-human labour and encounter value can indeed be different elsewhere where histories and pasts are set up by capital itself. Furthermore, it is important to recognize that are many different kinds of labour/bodies transformed into commodities, and their capture by capital can happen through multitudinous pasts.
} 


\begin{tabular}{|l|l|l|}
\hline Time & Clock time vs. 'free time' & Human-animal rhythms \\
\hline Production & Purposive & Intransitive \\
\hline Value & $\begin{array}{l}\text { Use vs. exchange } \\
\text { (inscriptive) }\end{array}$ & Encounter (relational) \\
\hline Exchange & $\begin{array}{l}\text { Pure gift vs. tradeable } \\
\text { commodity }\end{array}$ & $\begin{array}{l}\text { Trans-actions performed } \\
\text { between more-than-human } \\
\text { bodies }\end{array}$ \\
\hline
\end{tabular}

\section{References}

Anon., 2007a, "It's not about dying lions for Gujarat; it's all about pride" MINT Newswire, 8 August 2007

Anon., 2007b, "MP renews bid for lions' relocation" Hindustan Times, 17 April 2007

Bakker K, 2010, "The limits of "neoliberal natures": Debating green neoliberalism" Progress in Human Geography 34 715-735

Bakker K, Bridge G, 2006, "Material worlds? Resource geographies and the 'matter of nature'" Progress in Human Geography 30 5-27

Banerjee K, Jhala Y V, Chauhan K S, Dave C V, 2013, "Living with Lions: The Economics of Coexistence in the Gir Forests, India" PLoS ONE 8 e49457

Barua M, 2014a, "Bio-geo-graphy: landscape, dwelling and the political ecology of human-elephant relations" Environment and Planning D: Society and Space 32 915934

Barua M, 2014b, "Circulating elephants: unpacking the geographies of a cosmopolitan animal" Transactions of the Institute of British Geographers 39 559-573

Barua M, 2014c, "Volatile ecologies: towards a material politics of human-animal relations" Environment and Planning A 46 1462-1478

Barua M, 2015, "Encounter: Living Lexicon for the Environmental Humanities" Environmental Humanities 7 265-270

Berwick S, 1976, "The Gir Forest: An Endangered Ecosystem" American Scientist 64 2840

Bradshaw G A, 2009 Elephants on the edge: what animals teach us about humanity. (Yale University Press, New Haven)

Braun B, 2008, "Environmental issues: inventive life." Progress in Human Geography 32 667-679

Braun B, Whatmore S, 2010, "The Stuff of Politics: An Introduction", in Political matter: technoscience, democracy, and public life. Eds B Braun, S Whatmore (University of Minnesota Press, Minneapolis, MN) pp ix-xxxv

Brockington D, Duffy R, 2010, "Capitalism and conservation: the production and reproduction of biodiversity conservation" Antipode $\mathbf{4 2}$ 469-484

Brockington D, Duffy R, Igoe J, 2008 Nature Unbound: Conservation, Capitalism and the Future of Protected Areas (Earthscan, London) 
Brockington D, Scholfield K, 2010, "The Conservationist Mode of Production and Conservation NGOs in sub-Saharan Africa" Antipode 42 551-575

Caro T M, 2010 Conservation by Proxy. (Island Press, Washington DC)

Castree N, 1995, "The nature of produced nature: materiality and knowledge construction in Marxism" Antipode 27 12-48

Castree N, 2003, "Commodifying what nature?" Progress in Human Geography 27 273297

Castree N, 2010, "Neoliberalism and the Biophysical Environment 2: Theorising the Neoliberalisation of Nature" Geography Compass 4 1734-1746

Chakrabarty D, 2007 Provincializing Europe: Postcolonial Thought and Historical Difference (Princeton University Press, Princeton)

Collard R-C, 2013, "Putting Animals Back Together, Taking Commodities Apart" Annals of the Association of American Geographers 104 151-165

Collard R-C, Dempsey J, 2013, "Life for sale? The politics of lively commodities" Environment and Planning A 45 2682-2699

Davies G, 2000, "Virtual animals in electronic zoos: The changing geographies of animal capture and display.", in Animal spaces, beastly places: New geographies of humananimal relations. Eds C Philo, C Wilbert (Routledge, New York) pp 243-246

Deleuze G, 1988 Spinoza: Practical Philosophy (City Light Books, San Francisco, USA)

Divyabhanusinh, 2005 The Story of Asia's Lions (Marg Publications, New Delhi)

Divyabhanusinh, 2006, "Junagadh State and its Lions: Conservation in Princely India, 1879-1947" Conservation and Society 4 522-540

Duffy R, 2013, "The international political economy of tourism and the neoliberalisation of nature: Challenges posed by selling close interactions with animals" Review of International Political Economy 20 605-626

Duffy R, 2014, "Interactive elephants: Nature, tourism and neoliberalism" Annals of Tourism Research 44 88-101

Fenton L L, 1911, "The Kathiawar Lion" Journal of the Bombay Natural History Society 20 736-752

Gibson J J, 1986 The Ecological Approach to Visual Perception (Taylor \& Francis, New York)

Haraway D J, 2008 When species meet (University of Minnesota Press, Minneapolis, MN)

Harriss-White B, 2003 India Working: Essays on Society and Economy (Cambridge University Press, Cambridge)

Hinchliffe S, Kearnes M B, Degen M, Whatmore S, 2005, "Urban wild things: a cosmopolitical experiment." Environment and Planning D: Society and Space 23 643-658

Ingold T, 2000 The Perception of the Environment: Essays on livelihood, dwelling and skill. (Routledge, London)

Ingold T, 2011 Being Alive: Essays on Movement, Knowledge and Description. (Routledge, Abingdon, Oxon)

Jones 0, 2000, "(Un)ethical geographies of human- non-human relations: encounters, collectives and spaces", in Animal Spaces, Beastly Places: New Geographies of Human-Animal Relations. Eds C Philo, C Wilbert (Routledge, London) pp 268-291 
Joslin P, 1970, "Conserving the Asian Lion", in 11th Technical Meeting of the International Union for the Conservation of Nature, New Delhi, 25-28 Nov. 1969 (International Union for the Conservation of Nature Publications, New Series, Morges, Switzerland) pp 24-32

Kincaid C A, 2008 [1935], "Indian Lions", in The Lions of India Ed Divyabhanusinh (Permanent Black, Ranikhet) pp 65-73

Kurt F, Hartl G B, Tiedemann R, 1995, "Tuskless bulls in Asian elephant Elephas maximus. History and population genetics of a man-made phenomenon" Acta Theriologica, Suppl. 3 125-143

Lash S, Urry J, 1994 Economies of Signs and Space (SAGE Publications Ltd, London)

Lorimer J, 2007, "Non-human charisma." Environment and Planning D: Society and Space 25 911-932

Marx K, 1973 Grundrisse: Introduction to the Critique of Political Economy (Penguin Books Ltd, Harmondsworth, London)

Marx K, 1974, "Critique of the Gotha Programme", in The First International and After, Political Writings - Volume 3 Ed D Fernbach (Penguin Books Ltd., Harmondsworth, London) pp 339-359

Marx K, 1976 Capital: A Critique of Political Economy, Volume I (Penguin Books, London)

Marx K, 1977 Economic and Philosophic Manuscripts of 1844 (Progress Publishers, Moscow)

Mundy G C, 1832 Pen and Pencil Sketches, Being the Journal of Tour in India. Volume I. (John Murray, London)

Naveen P, 2013, "Land prices go up three times around Kuno sanctuary" The Times of India, 24 April 2013

Neves K, 2010, "Cashing in on Cetourism: A Critical Ecological Engagement with Dominant E-NGO Discourses on Whaling, Cetacean Conservation, and Whale Watching" Antipode 42 719-741

Ollman B, 1976 Alienation: Marx's concept of man in capitalist society (Cambridge University Press, Cambridge, UK)

Randeria S, 2003, "Glocalization of Law: Environmental Justice, World Bank, NGOs and the Cunning State in India" Current Sociology 51 305-328

Rangarajan M, 2013, "ANIMALS WITH RICH HISTORIES: THE CASE OF THE LIONS OF GIR FOREST, GUJARAT, INDIA" History and Theory 52 109-127

Robbins P, 2011 Political ecology: A critical introduction (Wiley-Blackwell, Oxford)

Romig R, 2013, "The Hard Life of Celebrity Elephants", http://timesofindia.indiatimes.com/city/kolkata/An-ElephantineProblem/articleshow/10100040.cms?

Rosdolsky R, 1977 The Making of Marx's 'Capital' (Pluto Press Limited, London)

Shotwell A, 2011 Knowing otherwise: race, gender, and implicit understanding (Pennsylvania State University, University Park, Pennsylvania)

Shukin N, 2009 Animal Capital: Rendering Life in Biopolitical Times (University of Minnesota Press, Minneapolis, MN)

Smitha R, 2012, "9,384 tourists in a day! Gir soars tourism record; nearly 23,000 tourists visited Gir sanctuary during Diwali holidays until November 16" Daily News \& Analysis, 17 November 2012 
Smitha R, 2013, "To part with Pride or not; Gujarat says next move only after reading SC order" Daily Nes \& Analysis, 16 April 2013

Thrift N, 2010, "Halos: Making More Room in the World for New Political Orders", in Political matter: technoscience, democracy, and public life. Eds B Braun, S Whatmore (University of Minnesota Press, Minneapolis, MN) pp 139-176

von Uexküll J, 1957, "A stroll through the worlds of animals and men", in Instinctive Behaviour Ed C Schiller (International Universities Press, New York) pp 5-80

von Uexküll J, 1982, "The Theory of Meaning" Semiotica 42 25-82

Walker P A, 2005, "Political ecology: where is the ecology?" Progress in Human Geography 29 73-82

Weber M, 1978 Economy and Society (University of California Press, Berkeley)

Whatmore S, 2002 Hybrid geographies: natures, cultures, spaces. (Sage, London)

Wilkie R, 2005, "Sentient commodities and productive paradoxes: the ambiguous nature of human-livestock relations in Northeast Scotland" Journal of Rural Studies 21 213-230

WWF, 2006, "Species fact sheet: Asian elephant", http://www.panda.org 